\title{
Diatoms diversity and dynamics in a southern Mediterranean lagoon (Mellah, Algeria)
}

\author{
Mohamed Anis Draredja I,*, Choukri Barour', Hocine Frihi², Chahinez Boualleg' \& Mohamed Laabir ${ }^{3}$ \\ ${ }^{1}$ Laboratory of Aquatic and Terrestrial Ecosystems, Faculty of Natural and Life Sciences, M.C. Messaadia University, 41000 \\ Souk Ahras, Algeria \\ ${ }^{2}$ Marine Bioresources Laboratory, Faculty of Sciences. Badji Mokhtar University, 23000 Annaba, Algeria \\ ${ }^{3}$ Center for Marine Biodiversity, Exploitation and Conservation (MARBEC), IRD, Ifremer, CNRS, University of Montpellier, \\ Place E. Bataillon, CC93, 34095 Montpellier cedex 5, France \\ ${ }^{*}$ Corresponding author, e-mail: draredjanis@gmail.com
}

ABSTRACT

KEY WORDS
The composition and distribution of diatoms were studied using a biweekly sampling performed in three representative stations in the Mellah Lagoon (South Western Mediterranean, Algeria), during 2016. In total, 160 diatoms species - belonging to centric species ( 52 species) and pennate species (108 species) - were inventoried. The relative abundance of the pennate forms $(67.50 \%)$ is clearly higher compared to the centric forms $(32.50 \%)$. The blooms of diatoms are represented by 3 species: Chaetoceros constrictus Gran, 1897 with up to 15000 cells.L-1 (end of May), Chaetoceros sp. with up to 178320 cells.L-1 (early October), and Nitzschia longissima (Brébisson) Ralfs, 1861 with up to 200640 cells.L L $^{-1}$ (early September). Proliferations of three potentially toxic species: Pseudo-nitzschia group delicatissima (Cleve) Heiden, 1928 (2500 cells.L-1 ${ }^{-1}$, Pseudo-nitzschia group seriata (Cleve) H. Peragallo, 1899 (700 cells. $\mathrm{L}^{-1}$ ) and Thalassionema nitzschoides (Grunow) Mereschkowsky, 1902 (210 cells. $\mathrm{L}^{-1}$ ), requires regular monitoring of this ecosystem where the exploitation of the shells is practiced. The diatom populations seem to be structured showing diversity (H') and equitability ( $\left.\mathrm{J}^{\prime}\right)$ indices reaching 4.56 bits.cell and 0.98 respectively, with the exception of springsummer and summer-autumn transition periods.

Algeria; diatoms; diversity; Mellah lagoon; harmful species.

Received 27.02.2019; accepted 16.05.2019; published online 18.06.2019.

\section{INTRODUCTION}

Coastal lagoons and adjacent wetlands play an important role in regulating environmental relations. Due to their multiple resources and proximity to the sea, they represent strategic locations for development and prosperity of human activities and therefore are subject to increasing anthropisation. These transitional ecosystems, between land and sea, are important ecosystems characterized by high biological productivity and biodiversity (Knoppers, 1994). However, the lagoons are very sensitive environments, fragile and extremely vulnerable, in relation to the organization of their living and non-living components which depends on the interaction between the natural components of the marine and continental areas (Dufour et al., 1994). Due to the wide variability of their physical, chemical and biological parameters, coastal lagoons are generally unstable environments. The 
short- or long-term variations that occur in these ecosystems are important compared to saline marine environments. Consequently, the spatial and temporal variability of the quality of their waters depends on the importance of river inputs, tidal flows and evaporation.

Diatoms are microscopic single-cell plants that live in fresh, brackish and marine waters, from the poles to the tropics (Trainer et al., 2008). Diatoms belonging to the class of Diatomophyceae (Bacillariophycea) are an extremely diverse group. Mann (1999) reports that this class is highly diversified with species number estimated between 0.1 and 1 million. Their high photosynthesis activity and their tendency to dominate phytoplankton communities have led to their major involvement in primary production. It has been estimated that diatoms contribute to $40-45 \%$ of ocean primary productivity, accounting for $20 \%$ of global carbon sequestration and oxygen production (Yool \& Tyrrell, 2003). They are the major phytoplankton in aquatic ecosystems and account for $20-25 \%$ of the oxygen release and carbon fixation in the world (Kale \&
Karthick, 2015). Diatoms are microalgae considered as the most sensitive to environmental conditions such as the organic pollution and the eutrophication (Licursia \& Gómeza, 2013) and water density (Drira et al., 2009). Some diatom species are directly or indirectly responsible for health problems (Lefebvre \& Robertson, 2010). Indeed some species especially the genus Pseudonitzschia $\mathrm{H}$. Peragallo in $\mathrm{H}$. Peragallo et $\mathrm{M}$. Peragallo, 1900, are toxic and produce powerful neurotoxins (domoic acid) that can cause illness and even death in the elderly community (Trainer et al., 2008).

Diatomophyceae have been studied in the Mediterranean basin (Caroppo et al., 2005; Sahraoui et al., 2009; Solak et al., 2018). However, despite their ecological and biological importance in the marine ecosystems, to our knowledge no study has been devoted to it in the Mellah lagoon. The aim of this study is to determine the species composition and distribution of diatoms in the well preserved Mellah lagoon, South Mediterranean, Algeria (Fig. 1).

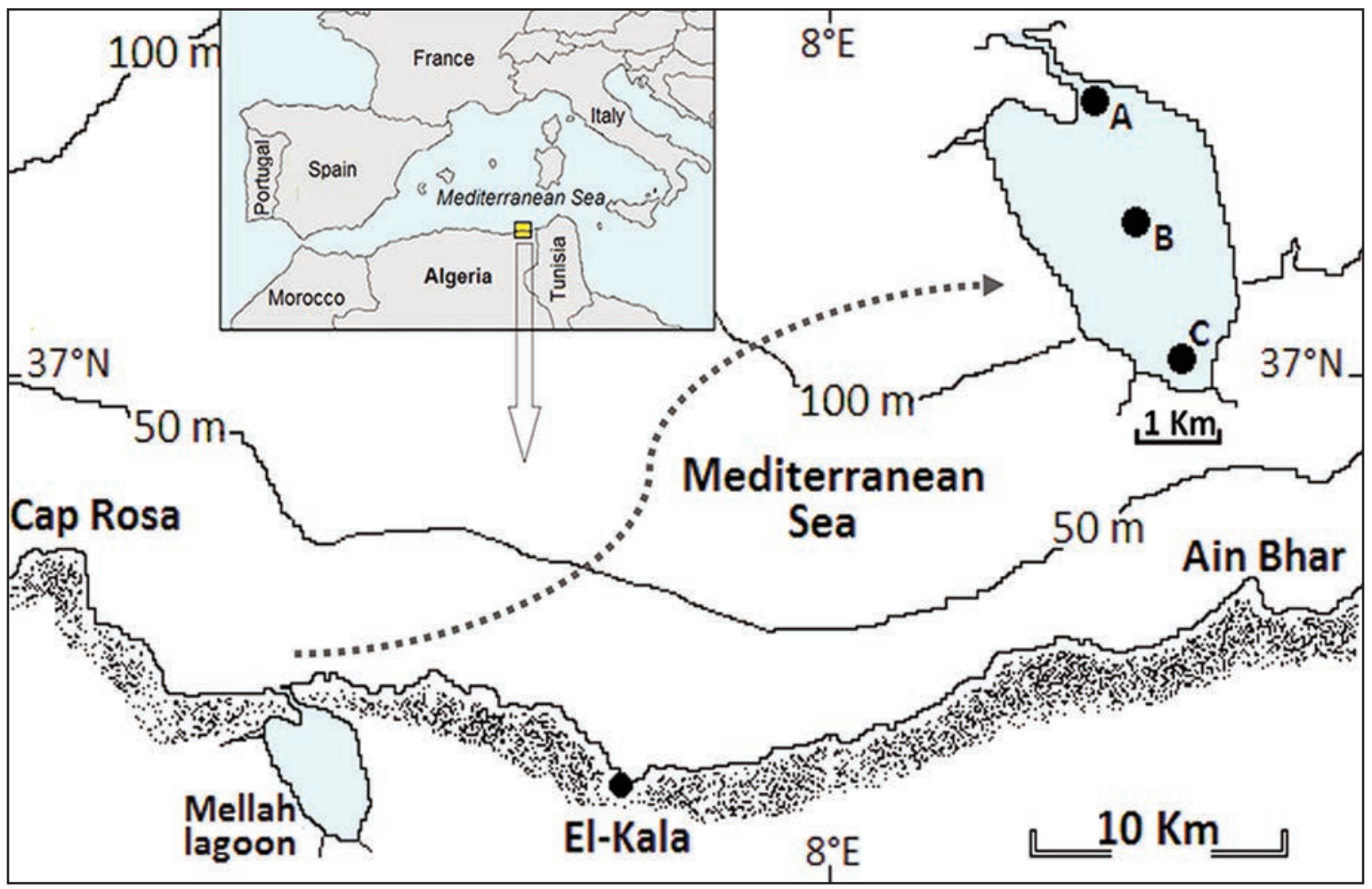

Figure 1. Geographical position of Mellah Lagoon and location of sampling stations (South Mediterranean, Algeria). 


\section{MATERIAL AND METHODS}

\section{Study area and location of stations}

The Mellah lagoon is located in the northeast of Algeria $\left(36^{\circ} 54^{\prime} \mathrm{N}-8^{\circ} 20^{\prime} \mathrm{E}\right)$, within the El-Kala National Park created in 1983, a protected natural reserve and classified as biosphere reserve in 1990. The Mellah lagoon has a surface of 865 ha (depth $<5 \mathrm{~m}$ ) and communicates with the sea by a channel (Fig. 1), which has undertaken substantial widening and deepening in 1988 (FAO, 1987) and is periodically dredged due to its recurrent filling with silt. The drainage system of the Mellah lagoon is characterized by three main intermittent streams located in southern sector of the lagoon, whose contribution to the overall nutrient loading is limited to the winter period. The Mellah lagoon is subject to a southern Mediterranean climate characterized by a dry and hot summer and a wet and cold winter.

During this study, three stations (St.A, St.B and St.C) were selected (Fig. 1): St.A (depth $2.50 \mathrm{~m}$ ), located in the north of the lagoon no far from the inflow of marine waters; St.B (depth $4.80 \mathrm{~m}$ ), situated in the center of the lagoon is the deepest zone and therefore under bathymetric influence; St.C (depth $1.50 \mathrm{~m}$ ), fixed in the south of the lagoon near the inflow of the two rivers (south and southwest of the lagoon), subject to freshwater influences.

\section{Physicochemical measurements, sampling and treatment of phytoplankton}

Sampling of phytoplankton and measurements of some physicochemical parameters were carried out in three stations every 15 days during the year 2016. Physicochemical measurements were carried out in situ using a multiparameter HANNA HI9828. While the nutrients (NH4, NO2, NO3 and PO4) were assessed by spectrophotometry.

Phytoplankton sampling was conducted, where a volume of 50 liters of water was filtered using a standard plankton net ( $20 \mu \mathrm{m}$ mesh size). Once collected, samples were fixed immediately with neutral formalin (concentration 4\%). Identification of diatom species was performed according to Hendey (1964), Sournia (1986), Ricard (1987), Round et al. (1990), Chretiennot-Dinet et al. (1993), Tomas (1996) and Hasle et al. (1996). In the present work a detailed study on the identification and counting has been reserved only to the class of Diatomophyceae. The number of cells was estimated using Utermöhl's method (Utermöhl, 1958). Both identification and quantification of cell abundance (cells. $\mathrm{L}^{-1}$ ) were made by an inverted light microscope (Leica DM750).

\section{Ecological indices and statistical analysis}

The spatiotemporal variation of the species rich-

\begin{tabular}{|llll|llll|}
\hline Variables & \multicolumn{1}{c}{ St.A } & \multicolumn{1}{c}{ St.B } & \multicolumn{1}{c|}{ St.C } & \multicolumn{1}{c}{ Winter } & \multicolumn{1}{c}{ Spring } & Summer & \multicolumn{1}{c|}{ Autumn } \\
\hline T & $20.11 \pm 5.48 \mathrm{a}$ & $20.37 \pm 5.61 \mathrm{a}$ & $20.44 \pm 5.53 \mathrm{a}$ & $13.64 \pm 1.31 \mathrm{a}$ & $22.06 \pm 2.36 \mathrm{~b}$ & $26.86 \pm 1.50 \mathrm{c}$ & $18.68 \pm 4.06 \mathrm{~b}$ \\
Sal. & $30.24 \pm 3.74 \mathrm{a}$ & $30.13 \pm 3.65 \mathrm{a}$ & $30.28 \pm 3.92 \mathrm{a}$ & $25.56 \pm 1.30 \mathrm{a}$ & $28.30 \pm 0.84 \mathrm{a}$ & $33.55 \pm 1.91 \mathrm{~b}$ & $33.46 \pm 1.33 \mathrm{~b}$ \\
DO & $7.30 \pm 0.79 \mathrm{a}$ & $7.30 \pm 0.81 \mathrm{a}$ & $7.00 \pm 0.86 \mathrm{a}$ & $7.54 \pm 0.66 \mathrm{a}$ & $7.33 \pm 0.90 \mathrm{a}$ & $6.80 \pm 0.72 \mathrm{a}$ & $7.13 \pm 0.87 \mathrm{a}$ \\
pH & $8.13 \pm 0.20 \mathrm{a}$ & $8.10 \pm 0.22 \mathrm{a}$ & $8.08 \pm 0.16 \mathrm{a}$ & $8.07 \pm 0.13 \mathrm{a}$ & $8.09 \pm 0.26 \mathrm{a}$ & $8.08 \pm 0.15 \mathrm{a}$ & $8.17 \pm 0.20 \mathrm{a}$ \\
SM & $16.80 \pm 7.93 \mathrm{a}$ & $16.16 \pm 7.89 \mathrm{a}$ & $16.14 \pm 9.56 \mathrm{a}$ & $27.47 \pm 5.00 \mathrm{a}$ & $14.16 \pm 5.90$ & $10.44 \pm 5.53 \mathrm{~b}$ & $13.38 \pm 4.54 \mathrm{~b}$ \\
NH4 & $1.82 \pm 1.62 \mathrm{a}$ & $1.74 \pm 1.55 \mathrm{a}$ & $1.94 \pm 1.68 \mathrm{a}$ & $2.54 \pm 1.98 \mathrm{a}$ & $2.35 \pm 0.80 \mathrm{a}$ & $1.59 \pm 1.33 \mathrm{a}, \mathrm{b}$ & $0.84 \pm 1.54 \mathrm{~b}$ \\
NO2 & $0.32 \pm 0.26 \mathrm{a}$ & $0.37 \pm 0.33 \mathrm{a}$ & $0.37 \pm 0.29 \mathrm{a}$ & $0.32 \pm 0.11 \mathrm{a}$ & $0.61 \pm 0.46 \mathrm{a}$ & $0.16 \pm 0.06 \mathrm{~b}$ & $0.33 \pm 0.14 \mathrm{a}$ \\
NO3 & $1.30 \pm 1.47 \mathrm{a}$ & $1.04 \pm 1.68 \mathrm{a}, \mathrm{b}$ & $0.59 \pm 0.72 \mathrm{~b}$ & $0.84 \pm 0.36 \mathrm{a}$ & $1.66 \pm 2.34 \mathrm{a}$ & $0.73 \pm 0.90 \mathrm{a}$ & $0.68 \pm 0.84 \mathrm{a}$ \\
DIN* & $3.44 \pm 2.16 \mathrm{a}$ & $3.15 \pm 2.61 \mathrm{a}$ & $2.89 \pm 2.00 \mathrm{a}$ & $3.70 \pm 2.17 \mathrm{ab}$ & $4.62 \pm 2.66 \mathrm{a}$ & $2.48 \pm 1.42 \mathrm{~b}, \mathrm{c}$ & $1.85 \pm 1.58 \mathrm{c}$ \\
PO4 & $0.60 \pm 0.55 \mathrm{a}$ & $0.54 \pm 0.49 \mathrm{a}$ & $0.48 \pm 0.42 \mathrm{a}$ & $0.57 \pm 0.52 \mathrm{a}$ & $0.68 \pm 0.58 \mathrm{a}$ & $0.44 \pm 0.29 \mathrm{a}$ & $0.47 \pm 0.50 \mathrm{a}$ \\
Chl. $a$ & $2.21 \pm 1.86 \mathrm{a}$ & $2.66 \pm 1.65 \mathrm{a}$ & $2.20 \pm 1.85 \mathrm{a}$ & $1.17 \pm 0.67 \mathrm{a}$ & $2.85 \pm 1.87 \mathrm{~b}$ & $3.35 \pm 1.59 \mathrm{~b}$ & $2.07 \pm 1.94 \mathrm{a}, \mathrm{b}$ \\
\hline
\end{tabular}

Table 1. Spatiotemporal variations (mean $\pm \mathrm{se}, \mathrm{n}=72)$ in temperature $\left(\mathrm{T},{ }^{\circ} \mathrm{C}\right)$, salinity (Sal., p.s.u.), dissolved oxygen (DO, mg. $\left.\mathrm{L}^{-1}\right), \mathrm{pH}$, suspended matter (SM, mg. $\left.\mathrm{L}^{-1}\right)$, ammonium (NH4, $\mu$ moles. $\left.\mathrm{L}^{-1}\right)$, nitrites $\left(\mathrm{NO} 2, \mu \mathrm{moles} . \mathrm{L}^{-1}\right)$, nitrates $(\mathrm{NO} 3$, $\mu$ moles. $\mathrm{L}^{-1}$ ), dissolved inorganic nitrogen (DIN, $\mu$ moles. $\left.\mathrm{L}^{-1}\right)$, phosphates (PO4, $\mu$ moles. $\mathrm{L}^{-1}$ ) and chlorophyll a $\left(\mathrm{Chl} . a, \mu \mathrm{g} . \mathrm{L}^{-}\right.$ $\left.{ }^{1}\right)$ in the Mellah lagoon waters. Different small letters indicate a significant difference between levels in each factor $(p<0.05)$, using the Dunn's test. $(*)$ : DIN $=$ NH4 $+\mathrm{NO} 2+\mathrm{NO} 3\left(\mu\right.$ moles. $\left.\mathrm{L}^{-1}\right)$. 
ness $(\mathrm{S})$ of diatoms group was calculated. The diversity index (H') used is that of Shannon \& Weaver (1949). The regularity index (J') was calculated using the method of Piélou (1966). Furthermore, a principal component analysis (PCA) was performed using the Factoextra (Kassambara \& Mundt, 2017) package on standardized data, whose objective is to characterize, by a multivariate approach, the structuring of spatiotemporal variations at the lagoon of Mellah. Statistical analyses were performed using $\mathrm{R}$, version 3.4.2 (R Core Team 2017; Ihaka \& Gentleman 1996) for Windows, by

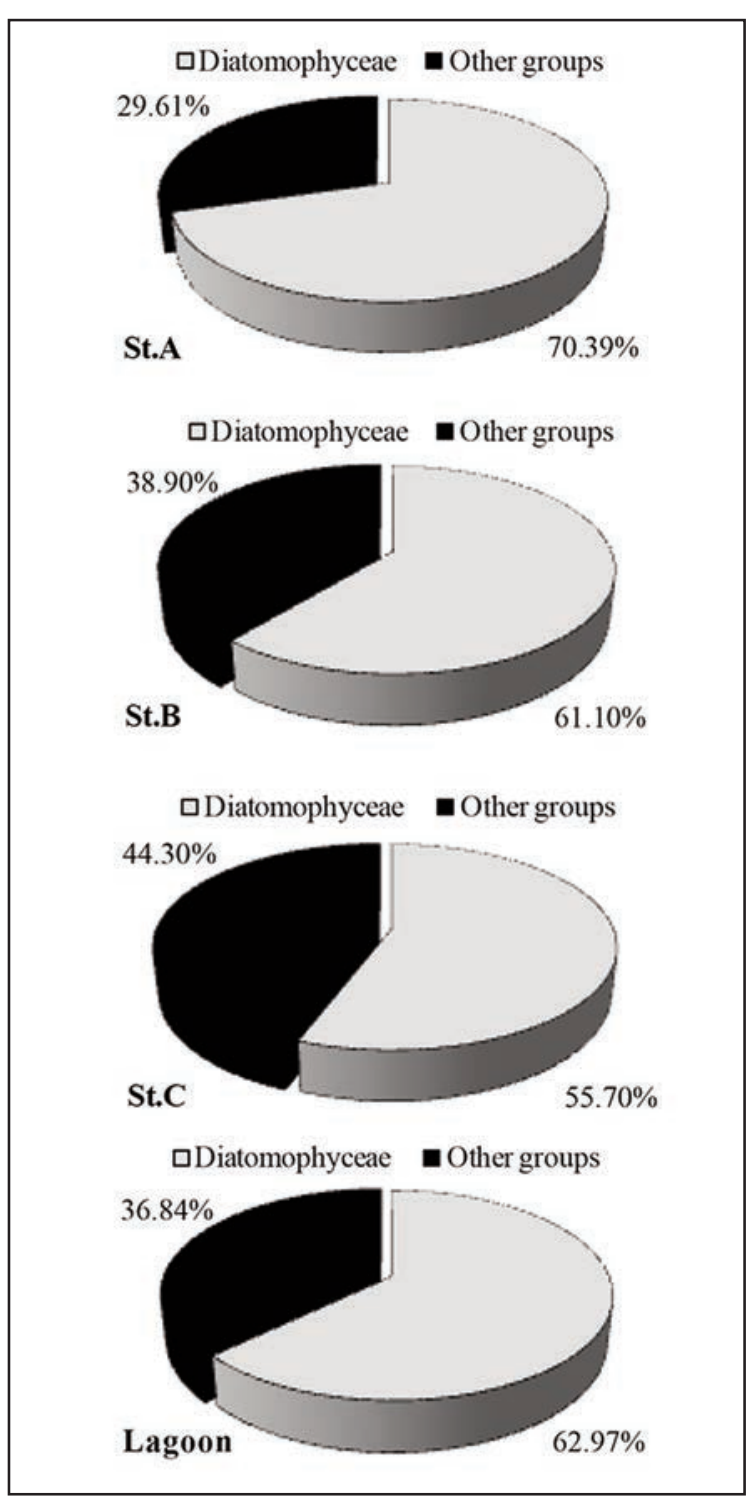

Figure 2. Relative abundances (\%) of diatoms in the phytoplankton of Mellah lagoon, Algeria (2016). using Dunn's test package (Dinno, 2017); median differences among seasons were tested by KruskalWallis test (rank-based nonparametric test) followed by post-hoc pairwise comparisons using Dunn's test with Holm's p-value adjustment. Results are given as means \pm standard error. All the statistical analyses were performed at the statistical significance of $\mathrm{p}<0.05$.

\section{RESULTS}

\section{Hydrological and environmental conditions}

The spatiotemporal variations of physicochemical parameters are represented in Table 1. The application of the Kruskal-Wallis test for the comparison of physicochemical parameters in water showed that for nearly all parameters (T, Sal., DO, pH, SM, NH4, NO2, DIN, PO4, Chla) no significant differences among the stations were recorded, with the exception of $\mathrm{NO} 3$ showing a minimum of $0.59 \pm 0.72 \mu$ moles. $L^{-1}$ at site $C$, and a maximum of $1.30 \pm 1.47 \mu$ moles. $\mathrm{L}^{-1}$ at site A.

The monitoring of seasonal variations of physicochemical factors in the Mellah lagoon indicates that there are significant differences for all parameters except DO, pH, NO3, PO4 (Table 1). This is why the temperature values oscillate between $13.64 \pm 1.31^{\circ} \mathrm{C}$ in winter and $26.86 \pm 1.50^{\circ} \mathrm{C}$ in summer. Salinity showed a variation between $25.56 \pm 1.30$ and $33.55 \pm 1.91$ p.s.u. in winter and summer, respectively. Results about the suspended matter showed that the mean values ranged from $10.44 \pm 5.53 \mathrm{mg} . \mathrm{L}^{-1}$ in summer to $27.47 \pm 5.00 \mathrm{mg}$. $\mathrm{L}^{-1}$ in winter. We found that nutrient salt concentrations vary between $0.84 \pm 1.54 \mu$ moles. $L^{-1}$ in autumn and $2.54 \pm 1.98 \mu$ moles. $\mathrm{L}^{-1}$ in winter for NH4; between $0.16 \pm 0.66 \mu$ moles. $L^{-1}$ in summer and $0.61 \pm 0.46 \mu$ moles. $\mathrm{L}^{-1}$ in spring for $\mathrm{NO} 2$; between $1.85 \pm 1.58 \mu$ moles. $L^{-1}$ in autumn and 4.62 \pm 2.66 $\mu$ moles. $\mathrm{L}^{-1}$ in spring for DIN. The winter period was characterized by the lowest Chlorophyll a means with $1.17 \pm 0.67 \mu \mathrm{g} . \mathrm{L}^{-1}$ in winter, while the highest mean values were in the summer period with $3.35 \pm 1.59 \mu \mathrm{g} . \mathrm{L}^{-1}$.

\section{Composition of diatom communities}

Diatom composition of Mellah lagoon was char- 
acterized by a mixture of marine, brackish-water and freshwater taxa. Diatoms formed the most dominant group and contributed greatly to the total phytoplankton at almost all the stations (55.70-70.39\%) (Fig. 2). Over $62.97 \%$ of total phytoplankton taxa were represented throughout the lagoon. In all stations we identified 160 species belonging to the Diatomophyceae (Table 2). The diatoms were represented by 52 centric and 108 pennate species. Among the Centrales, several families such as Catenulaceae (15 species), Thalassiosiraceae (8 species) and Triceratiaceae (5 species) were recorded, while for the Pennates, three were the most rich in species: Bacillariaceae (22 species), Naviculaceae (16 species) and Pleurosigmataceae (14 species) (Table 2). However, in the three stations the centric forms are dominant (50.01$92.15 \%$ ), compared to the pennate forms.

\section{Population density and distribution}

The spatiotemporal variation in the density of diatoms is reported in figure 3. The maximum density of this phytoplankton group varies be-

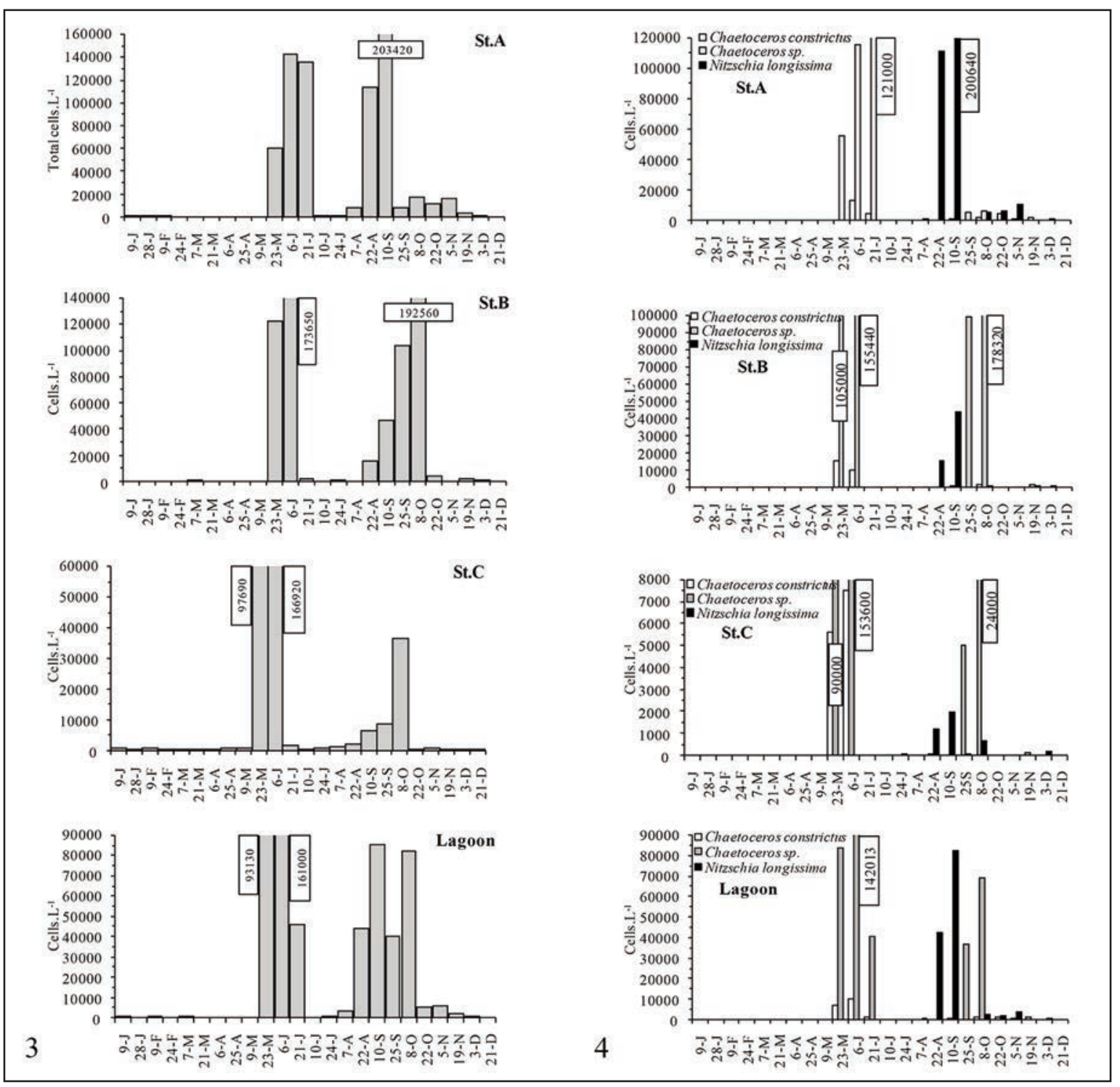

Figure 3. Spatiotemporal variations of density (cells.L-1 $)$ of diatoms collected in the Mellah lagoon, Algeria (2016). Figure 4. Spatiotemporal variations of abundance (cells. $\left.L^{-1}\right)$ of diatom species with efflorescence in the Mellah lagoon, Algeria (2016). 


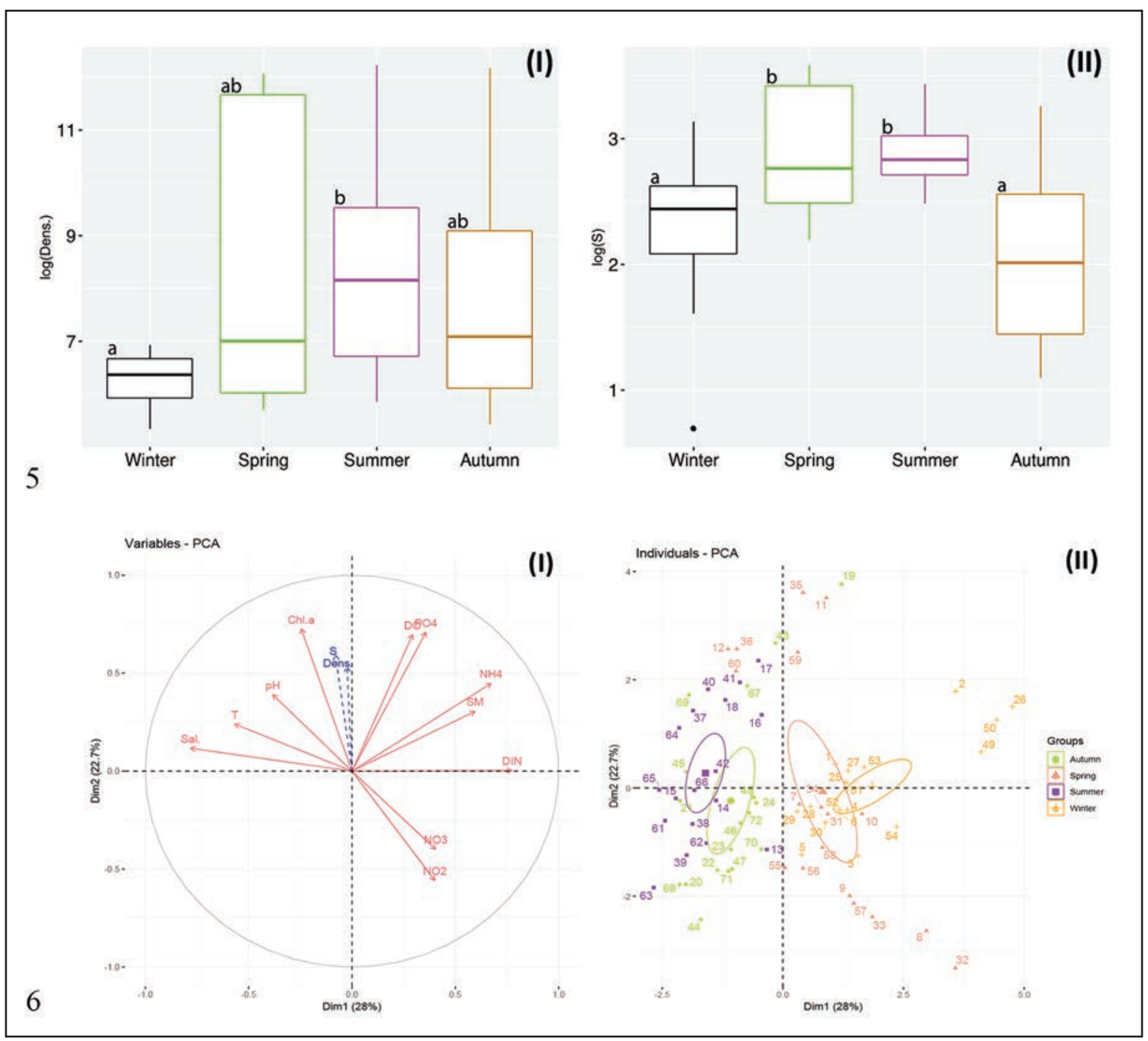

Figure 5. Seasonal variations in density (Dens.) (I) and species richness (S) (II) of diatoms in the Mellah lagoon ( $\mathrm{n}=72$ ). Boxplots labeled with the same letter are not significantly different at $\mathrm{p}<0.05$. Central box limits show the interquartile range (IQR) with the first (lower box bound) and third (upper box bound) quartiles. Outliers (values outside IQR limits \pm 1.58 times IQR) are indicated by small circles.

Figure 6. Principal Component Analysis (PCA) based on correlation between diatoms density and species richness and the environmental parameters (I); PCA analysis score plot (Dim1 vs Dim2) based on the monitored seasons in the Mellah lagoon (II). (Factorial plane: $\operatorname{Dim} 1=28 \%$, Dim2 $=22.70 \%$ ).

tween 97690 cells.L - $^{-1}$ (St.C, end of May) and 203420 cells. $L^{-1}$ (St.A, early September). According to the period and the station, among the 160 species only a few (about three) are clearly dominant. The majority of the species are therefore very poorly represented. The species that are responsible for high abundances are shown in figure 4 . Only 3 species causing blooms were detected: Chaetoceros sp. with up to 178320 cells.L-1 (St.B, early October), Chaetoceros constrictus with up to 15000 cells. $\mathrm{L}^{-1}$ (St.B, end of May) and Nitsctzschia longissima with up to 200640 cells.L L $^{-1}$ (St.A, early September). The list of the microalgae contains three species classified as potentially toxic: Pseudonitzschia delicatissima (2520 cells. L $^{-1}$, St.A, early November), P. seriata (700 cells.L ${ }^{-1}$, St.A, early November) and Thalassionema nitzschoides (210 cells. $\mathrm{L}^{-1}$, St.B, end of September). The application of the Kruskal-Wallis test for density and specific richness showed that there is a significant difference 
among seasons and no significant differences among stations. The inter seasonal variations of diatoms density and specific richness in the lagoon are reported in figure 5, I. Regarding density, the extreme mean values are $590.56 \pm 266.45$ cells. $\mathrm{L}^{-1}$ in winter and 50295.56 \pm 6817.43 cells. $\mathrm{L}^{-1}$ in spring. However, seasonal variation of diatoms showed different dispersions. Concerning the qualitative composition, the differences in mean inter seasonal values are also important, because they varied between $9.89 \pm 7.12$ in autumn and 20.28 \pm 9.78 in spring (Fig. 5, II).

The use of Principal Component Analysis (PCA) as a preliminary and exploratory descriptive approach made it possible to visualize the structuring of the seasonal and spatial variation in the three stations according to 11 physicochemical variables: water temperature ( $\mathrm{T}), \mathrm{pH}$, salinity (Sal.), dissolved oxygen (DO), nitrates (NO3), nitrites (NO2), Ammonium (NH4), dissolved inorganic nitrogen (DIN) phosphates (PO4), suspended matter (SM), chlorophyll a (chl. a), and two biological variables: specific richness (S) and density (Dens.) (Fig. 6).

The PCA clearly shows that the first two factorial axes yielded nearly $50.70 \%$ of the information (Fig. 6, I). Axis 1, explaining $28 \%$ of the total variation, is positively correlated with the variables DIN ( $r=0.77)$, NH4 $(r=0.67), \mathrm{SM}(\mathrm{r}=0.59)$, which strongly contribute to the construction of this axis ( $\cos ^{2}=0.6, \cos ^{2}=0.45, \cos ^{2}=0.35$, respectively); and negatively with the variables Sal. $(\mathrm{r}=-0.78), \mathrm{T}(\mathrm{r}=$ $-0.57)$ and $\mathrm{pH}(\mathrm{r}=-0.38)$, which also contribute significantly to its construction $\left(\cos ^{2}=0.61, \cos ^{2}=0.32\right.$ and $\cos ^{2}=0.15$, respectively). In addition, axis 2 , explaining $22.7 \%$ of the total variation, is built mainly by the strong positive correlations of the variables Chl.a (r=0.73), PO4 (r=0.71), DO (r=0.70), S $(\mathrm{r}=0.59)$ and Dens. $(\mathrm{r}=0.53)$ and the negative correlation of variables $\mathrm{NO} 2(\mathrm{r}=-0.56)$ and $\mathrm{NO} 3(\mathrm{r}=$ $-0.40)$ which contribute considerably to its construction $\quad\left(\cos ^{2}=0.53, \quad \cos ^{2}=0.50, \quad \cos ^{2}=0.49\right.$, $\cos ^{2}=0.35, \cos ^{2}=0.28, \cos ^{2}=0.31$ and $\cos ^{2}=0.16$ respectively). Regarding seasonal variation (Fig. 6, II), we noted that summer is characterized by high values of salinity and temperature. In autumn it's $\mathrm{pH}, \mathrm{Chl} . a$, density and the specific richness of diatoms which dominate. Spring is characterized by higher concentrations of DO, PO4, NO2, NO3. Finally, $\mathrm{NH} 4, \mathrm{SM}$, and DIN dominate during winter season.

\section{Species diversity and ecological indices}

The number of species (S) and range of diversity indices in the study area are shown in figure 7. In particular, the maximum number of species (36) was observed in the north of the Mellah at St.A (early June); St.C, in the south of the Mellah, was the least rich ( 32 species, end of June) and St.B, in the center of the lagoon, was characterized by a specific richness of 34 species. Shannon index of diversity $\left(H^{\prime}\right)$ values generally increased in parallel to the number of species $(\mathrm{S})$ and evenness index $(\mathrm{J}$ ') throughout the study period. This trend was observed only for stable ecosystems. This is not the case of the Mellah lagoon, which is characterized by the fact that it is punctually pound during ad-

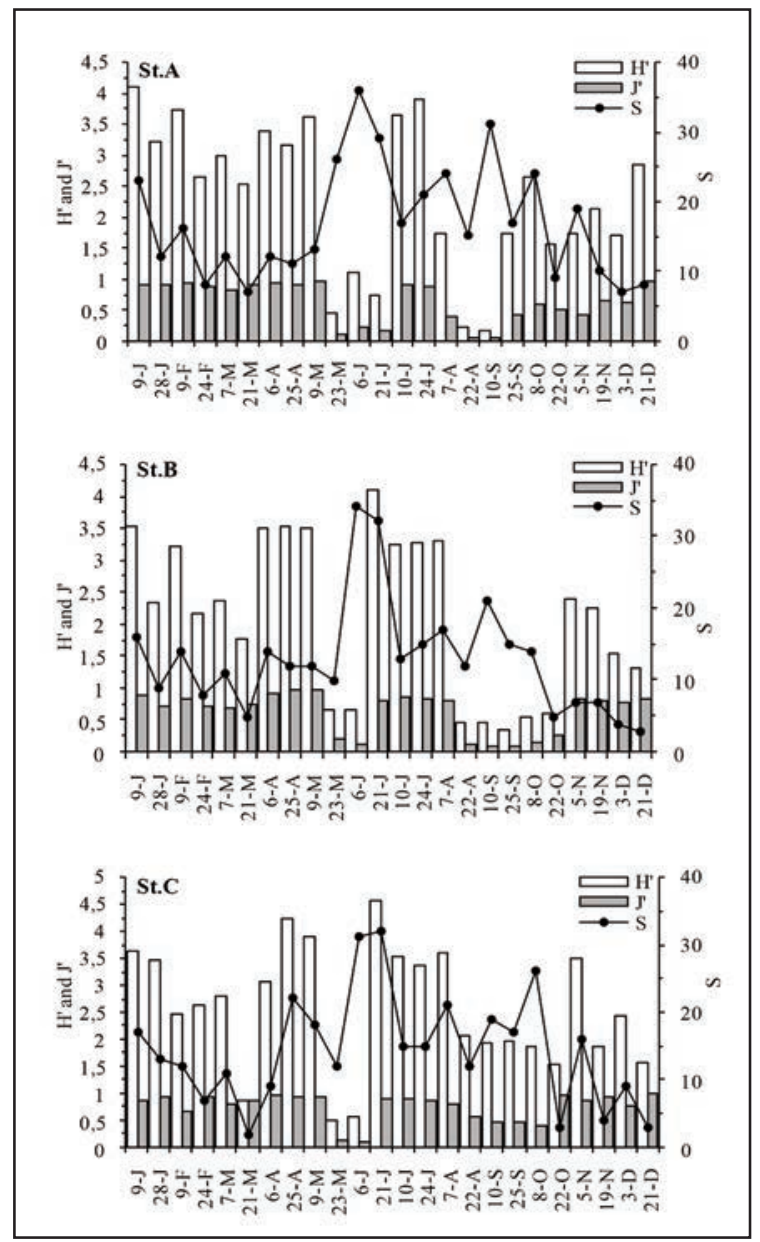

Figure 7. Spatio-temporal variations of species number (S), Shannon diversity index (H') and Piélou evenness index (J') of diatoms in the Mellah lagoon, Algeria (2016). 


\section{CENTRIC}

Catenulaceae Mereschkowsky, 1902 Amphora arenaria Donkin, 1858 (M) A. coffeaeformis (C. Agardh) Kützing, 1844 (M)

A. decussata Grunow, 1877 (M)

A. dubia Gregory, 1857 (M)

A. gigantea Grunow (M)

A. laevis Gregory, $1857(\mathrm{M})$

A. lineolata Ehrenberg, $1838(\mathrm{M})$

A. marina W.Smith, 1857 (M)

A. ocellata Donkin, 1861 (M)

A. ovalis (Kützing) Kützing, 1844 (M)

A. proboscidea Gregory, 1857 (M)

A. proteus Gregory, 1857 (M)

A. ostrearia Brébisson, 1849 (M)

A. sulcata Brébisson, 1854 (M)

A. terroris Ehrenberg, 1853 (M)

\section{Chaetocerotaceae Ralfs, 1851}

Chaetoceros constrictus Gran, 1897 (M)

C. pseudobrevis Pavillard, 1911 (M)

C. radicans $\mathrm{F}$. Schütt, 1895 (M)

Chaetoceros sp.

Coscinodiscaceae Kützing, 1844

Coscinodiscus centralis Ehrenberg, 1844 (M)

C. obscurus Schmidt, 1858 (M)

C. subtilis Ehrenberg, 1841 (M)

Coscinodiscus sp.

Hyalodiscaceae Crawford, 1990

Hyalodiscus scoticus (Kützing) Grunow 1879 (M)

Podosira stelligera (Bailey) A. Mann, 1907 (M)

Hemidiscaceae Hendey, 1937 emend Simonsen, 1975 Pseudoguinardia recta Von Stosch, 1986 (F)

Lauderiaceae (Schütt) Lemmermann, 1899, sensu emend. Lauderia borealis Gran, 1900 (M)

Leptocylindraceae Lebour, 1930

Leptocylindrus danicus Cleve, 1889 (M)

LithosdemiaceaeRound, 1990

Lithodesmium undulatum Ehrenberg, 1839 (M)

Melosiraceae Kützing, 1844, sensu emend. Melosira moniliformis (O.F. Müller) C. Agardh, 1824 (M) M. nummuloides C. Agardh, 1824 (M)

Melosira sp.

Paraliaceae Crawford, 1988

Paralia sulcata (Ehrenberg) Cleve, 1873 (L)

Rhizosoleniaceae De Toni, 1890

Guinardia flaccida (Castracane) H. Peragallo, 1892 (M)

Rhizosolenia delicatula Cleve, 1900 (M)

R. imbricata Brightwell, 1858 (M)

R. stolterfothii H. Peragallo, 1888 (M)

Skeletonemaceae Lebour, 1930, sensu emend.

Skeletonema costatum (Greville) Cleve, 1873 (M)

Syracosphaeraceae Lemmermann, 1908

Syracosphaera pulchra Lohmann, 1902 (M)
Thalassiosiraceae Lebour, 1930

Planktoniella sol (C.G. Wallich) Schütt, 1892 (M)

Thalassiosira fallax Meunier, 1910 (M, L, F)

T. lineata Jousé, 1968 (M)

T. nordenskioeldii Cleve, 1873 (M)

T. visurgis Hustedt, 1957 (L, F)

Triceratiaceae (Schütt) Lemmermann, 1899

Auliscus caelatus Bailey, 1854 (M)

Cerataulus radiatus $\mathrm{R}$. Rross, 1986 (M)

Odontella cf. rostrata (Hustedt) Simonsen, 1987 (M, L)

Triceratium antediluvianum (Ehrenberg) Grunow, 1868

T. favis Ehrenberg, 1839 (M)

T. pelagicum(J.L.B. Schröder) Sournia, 1968 (M)

T. shadboltianumR.K. Greville, 1862 (M)

Triceratium sp.

\section{PENNATE}

Achnanthaceae Kützing, 1844

Achnanthes brevipes Agardh (L)

Amphipleuraceae Grunow, 1862

Amphiprora hyperborea (Grunow, 1880) (M)

Amphiprora sulcata (O'Meara, 1871) (M)

Amphiprora sp.

Auriculaceae Hendy, 1964

Auricula amphitritis Castracane, 1873 (M)

Bacillariaceae Ehrenberg, 1831

Bacillaria paradoxa J.F.Gmelin in Linnaeus, 1791 (M)

Hantzschia virgata (Roper) Grunow in Cleve \&

Grunow 1880 (M)

Nitzschia acula (Kützing) Hantzsch in Rabenhorst, 1861 (F)

N. acuminata (W. Smith) Grunow, 1880 (M)

N. angularis Smith, $1853(\mathrm{M})$

N. closterium Eulenstein, 1868 (F)

N. constricta (Gregory) Grunow, $1880(\mathrm{~F})$

N. cylindrus (Grunow ex Cleve) Hasle, 1972 (M)

N. dubia W. Smith, 1853 (F)

N. fasciculata (Grunow) Grunow in Van Heurck, 1881 (F)

N. incurva Grunow in O. Schneider, 1878 (F)

N. linearis W.Smith, 1853 (M, F)

N. longissima (Brébisson) Ralfs, 1861 (F)

N. obtusa W. Smith, 1853 (M, F)

N. polaris Grunow ex Cleve, $1883(\mathrm{M})$

N. punctata (W. Smith) Grunow, 1878 (M)

N. sigma (Kützing) W. Smith, 1853 (F)

N. spathulata W. Smith, 1853 (M)

$N$. ventricosa Kitton, 1873 (M)

Nitzschia sp.

Pseudo-nitzschia delicatissima (Cleve) Heiden, $1928\left(\mathrm{~N}^{\mathfrak{l}}\right)(\mathrm{T})$

P. seriata (Cleve) H.Peragallo, 1899 (M) (T)

Climacospheniaceae

Climacosphenia monoligera Ehrenberg, 1843 (M)

Cocconeidaceae Kützing, 1844

Cocconeis molesta Kützing (M)

C. placentula Ehrenberg, 1838 (M)

C. pseudomarginata Gregory, 1857 (M)

C. stauroneiformis (W. Smith) H. Okuno, 1957 (M)

Cocconeis sp. 
Cymatosiraceae Hasle, von Stosch \& Syvertsen, 1983 Campylosira cymbelliformis (A. Schmidt) Grunow ex Van Heurck, 1885 (M)

Minutocellus scriptus Hasle, von Stosch \& Syvertsen, 1983 (M)

Cymbellaceae (Greville, 1833)

Cymbella cymbiformis (Ehrenberg) Grunow in Van Heurck, $1880(\mathrm{M})$

Cymbella inaequalis Ross, 1852 (M)

Cymbella helvetica Schmidt in Schmidt et al., 1881 (F)

Diploneidaceae D.G. Mann, 1990

Diploneis bomboides(A.W.F. Schmidt) Cleve, 1894 (M)

D. bombus (Ehrenberg) Ehrenberg, 1853 (M)

D. crabro (Ehrenberg) Ehrenberg, 1854 (L)

D. didyma (Ehrenberg) Ehrenberg, 1839 (M)

D. incurvata (Gregory) Cleve, 1894 (M)

Diploneis sp.

Fragilariacées (Dumortier, 1823)

Fragilaria islandica Grunow ex Van Heurck, 1881 (M) Synedra acus Kützing, 1844 (F)

S. cristallina $(\mathrm{L}, \mathrm{F})$

S. fasciculata Ehrenberg, 1832 (F)

S. ulna (Kützing) Skabichevskii, 1959 (F)

Synedra sp.

\section{Licmophoraceae Kützing, 1844}

Licmophora abbreviata C. Agardh, 1831 (M)

L. ehrenbergii (Kützing) Grunow, 1867 (M)

L. flabellata (Greville) Agardh (M)

L. reichardtii Grunow, 1881 (M)

L. robusta H. Peragallo \& M. Peragallo (M)

L. tenuis (Kützing) Grunow, 1867 (M)

Licmophora cf. tincta (C. Agardh) Grunow, 1868 (M)

Lyrellaceae D.G. Mann

Lyrella hennedyi (W.Smith) Stickle \& D.G. Mann, 1990

\section{Naviculaceae (Kützing, 1844)}

Haslea ostrearia (Gaillon) Simonsen, 1974 (M)

H. wawrikae (Hustedt) Simonsen, 1974 (M)

Navicula cryptocephala Kützing, 1844 (M)

N. distans (W. Smith) Ralfs, 1861 (M, L)

N. flanatica Grunow, 1860 (L, F)

N. gregaria Donkin, 1861 (M, L, F)

N. pavillardi Hustedt, 1939 (L)

N. pennata A.W.F. Schmidt (F)

N. pupula Bristol, 1920 (F)

N. radiosa Kützing, $1844(\mathrm{~F})$

N. ramosissima (C. Agardh) Cleve, 1895 (M)

N. retusa H. Lange-Bertalot \& K. Bonik, 1976 (M, L)

N. salinarum Grunow, 1880 (L, F)

N. spicula (Hickie) Cleve, 1894 (M, F)

N. viridula Neupauer, 1867 (F)
Navicula sp.

Pinnulariaceae D.G. Mann, 1990

Oestrupia sp. (M)

Plagiotropidaceae D.G. Mann

Plagiotropis lepidoptera (Gregory) Kuntze, 1898 (L)

P. conserta (Lewis) Kuntze, 1898 (M)

P. vitrea (W. Smith) Grunow, 1880 (M)

Plagiotropis sp.

Pleurosigmataceae Mereschkowsky, 1903

Gyrosigma balticum (Ehrenberg) Rabenhorst, 1853 (M)

G. distortum (W. Smith) Griffith \& Henfrey, 1856 (M, F)

G. littorale (W. Smith) Griffith \& Henfrey, 1856 (M)

G. prolongatum (W.Smith) J.W.Griffith \& Henfrey 1856 (M)

G. scalproides (Rabenhorst) Cleve, 1894 (L, F)

Pleurosigma angulatum (Queckett) W.Smith, 1852 (M)

$P$, delicatulum W. Smith, $1852(\mathrm{M}, \mathrm{L})$

P. elongatum W.Smith, $1852(\mathrm{M}, \mathrm{L}, \mathrm{F})$

P. formosum W. Smith, 1852 (L)

P. giganteum Grunow, 1880

P. lanceolatum Donkin, 1858 (M)

P. obscurum W. Smith, 1852 (L)

P. stuxbergi Cleve \& Grunow, 1880 (M)

Pleurosigma sp.

Rhabdonemataceae Round \& R.M. Crawford

Rhabdonema adriaticum Kützing, 1844 (M)

R. arcuatum Kützing, 1844 (M)

Rhopalodiaceae (Karsten) Topachevs'kyj \& Oksiyuk, 1960 Epithemia turgida (Ehrenberg) Kützing, 1844 (F)

Stauroneidaceae D.G.Mann, 1990

Stauroneis africana Amossé, 1934

S. spicula Hickie, 1874 (M)

Striatellaceae Kützing, 1844

Grammatophora oceanica Ehrenberg, 1840 (M)

Striatella unipunctata (Lyngbye) C. Agardh, 1832 (M)

Surirellaceae Kützing, 1844

Campylodiscus fastuosis Ehrenberg, 1845 (M)

Surirella fastuosa (Ehrenberg) Ehrenberg, 1843 (M)

S. ovataEhrenberg, 1844 (1845) (F)

S. striatula Turpin, $1828(\mathrm{M})$

Tebellariaceae Kützing, 1844

Tabellaria fenestrata (Cleve) Skabichevskii, 1960 (M)

Thalassionemataceae Round, 1990

Thalassionema nitzschioides (Grunow) Mereschkowsky, 1902 (M) (T)

Thalassiothrix delicatula Cupp, 1943 (M)

T. longissima Cleve \& Grunow, 1880 (M)

Table 2. Check list of diatoms species identified in Mellah lagoon, Algeria (2016).

F: freshwater, M: marine, L: lagoon, T: potentially toxic).

Classification depending on Website WoRMS: http://www.marinespecies.org/ and AlgaeBase: http://www.algaebase.org). 
verse situations. The highest diversity $\left(\mathrm{H}^{\prime}=4.56\right.$ bits/cell) was observed at St.C (end of June) and the lowest value $\left(\mathrm{H}^{\prime}=0.15 \mathrm{bits} /\right.$ cell $)$ was detected at St.A (early September), while Piélou evenness index varies between 0.03 (St.A, early September) and 0.98 (St.C, end of December) (see Fig. 7).

\section{DISCUSSION AND CONCLUSIONS}

Our results highlighted the hydrological peculiarities of this lagoon ecosystem. The thermal variations of Mellah lagoon waters $\left(12.26-28.26^{\circ} \mathrm{C}\right)$ are comparable to the majority of southern Mediterranean lagoons (Béjaoui et al., 2010; El-Madani et al., 2011; Bellakhal Fertouna \& Bellakhal, 2013; Dhib et al., 2016). However, the salinity extreme values (23.98-36.23 p.s.u.) are often lower compared with ecosystems of neighboring countries including Bizerte lagoon in Tunisia (Sahraoui et al., 2009; Béjaoui et al., 2010) and Nador lagoon in Morocco (El-Madani et al., 2011). Overall Mellah lagoon waters are well oxygenated unlike some Mediterranean lagoons which are characterized by periodic dystrophy crisis when the dissolved oxygen can reach critical values (Lenzi et al. 2003; Viaroli et al., 2006; Marinov et al., 2008; El Madani et al., 2011; Pachés et al., 2014).

Regarding the spatiotemporal distribution of nutrients, unlike the majority of Mediterranean lagoons which are often characterized by a significant enrichment in nutrient salts (Souchu et al., 2010; El Madani et al., 2011; Satta et al., 2014; Pachés et al., 2014; Zaaboub et al., 2014), the Mellah lagoon, due to its waters less rich in nutrients, ranks among the meso-oligotrophic lagoons (OECD, 1982). These particular physicochemical characteristics lead to a low chlorophyll a production not exceeding 5.84 $\mu \mathrm{g} . \mathrm{L}^{-1}$ with an annual average of $2.41 \mu \mathrm{g} . \mathrm{L}^{-1}$. These values are often low compared to several lagoons in the Mediterranean (Badosa et al., 2008; Roselli et al., 2009; Cañedo-Argüelles et al., 2012; Bernardi Aubry et al., 2013; Pachés et al., 2014). This physicochemical and hydrological situation is the result of a double effect. First, the Mellah Lagoon is a body of water that is located within the El-Kala National Park; a protected nature reserve since 1983 , so far from any source of pollution or anthropogenic action. Then, the narrowing of the communication channel with the sea, which has not been dredged since 1988, has further reduced water exchanges with the adjacent Mediterranean coast (Ounissi et al., 2002). In addition, in this region there is a low urbanization limited to a few houses of traditional construction.

The majority of species belong to diatoms, many of which have a benthic affinity. These forms of diatoms are still common in lagoon environments as highlighted by Mallissen \& Lasserre (1979). It appears that the richness of diatoms is related not only to tidal regime turbulence (leading to benthic and tychopelagic forms in the water column), but also to their ability to directly draw nutrients from the water-sediment interface (Bonin, 1988). Investigating diatoms in the Mellah lagoon allowed us to identify 160 taxa, most of which belonging to the marine contingent. The typical lagoon species are very few (only 16). Although the low nutrient levels, the number of diatom species reached 160. Interestingly, this moderate diatom specific richness observed in Mellah lagoon exceeded those of some other Mediterranean ecosystems: Lake of Tunis (Benrejeb-Jenhani \& Romdhane, 2002), two lagoons in the Sfax saltern (Ayadi et al., 2004), Nador lagoon (El Madani et al., 2011), Venice lagoon (Bernardi Aubry et al., 2013) and Cullera Estany lagoon (Pachés et al., 2014).

In the present study, the maximum number of taxa (53) is observed at station A, situated in the north of the Mellah lagoon in front of the channel communicating with the sea, therefore under marine influence. The minimum number of taxa (43) is found at Station $\mathrm{C}$, confined in the extreme south of the lagoon and under continental influence. The difference in species richness between these two sites shows that several phytoplankton populations come from the adjacent coast by the channel that connects the lagoon to the sea. In the Mellah lagoon, diatoms are the dominant (qualitatively and quantitatively) group within microphytoplankton. This dominance characterizes not only the majority of Mediterranean lagoons (Benrejeb-Jenhani \& Romdhane, 2002; Bernardi Aubry \& Acri 2004; El Madani et al., 2011; Bernardi Aubry et al., 2013; Nassar \& Gharib, 2014), but also the waters of the open Mediterranean coast (Percopo et al., 2011; Drira et al., 2014; Taş, 2014; Khairy \& Gharib, 2017; Rekik et al., 2017). However, despite the meso-oligotrophy of the Mellah lagoon, we can observe that the number of diatom cells were rela- 
tively important (up to 203420 cells. $\mathrm{L}^{-1}$ ) in the north of the lagoon. This zone of the lagoon could form a site for accumulation of marine species (brought back by the channel during the flow phase) and, to a lesser extent, for the arrivals of freshwater tolerant species transported by the three rivers that discharge there. In the Mellah lagoon, the main blooming species is Nitzschia longissama with a maximum abundance of 200640 cells. $L^{-1}$ recorded at Station A (north of the lagoon), in the end of summer. The end of the bloom could result from increasing oxygen demand and the decrease of nutrients.

The application of the Kruskal-Wallis test for the abundance showed that there is a significant difference among the seasons. The Principal Component Analysis (PCA) explains the positive role played by nutrients (mainly with PO4 and secondary with $\mathrm{NH} 4$ ) in the proliferation and diversification of diatoms. Indeed, the meso-oligotrophic character of the waters of the lagoon implies the role played by these nutrients as soon as they increase in the water column. Though high temperature and salinity during the summer season limit the proliferation of this group of phytoplankton, nevertheless, diatoms in the Mellah lagoon are characterized by optimal development and structuring during the spring-summer and summer-autumn transition phases, when thermal conditions are moderate.

Diatom populations of the Mellah lagoon showed a diversity that can reach 4.56 bits.cell.-1 and a regularity of 0.98 , thus suggesting structured diatom populations for only a period of the year (winter and end of spring). However, the rest of the cycle is characterized by an unstable species composition. In this case, only the opportunistic species develop, well adapted to the unfavorable environmental factors (mostly temperature) (Mozetic et al., 1998; Bianchi et al., 2003). We noted that the maximum values of diversity ( $\left.\mathrm{H}^{\prime}\right)$ in the Mellah lagoon are higher than those recorded in other Mediterranean lagoons. Indeed, in the Venice lagoon (Italy) Bernardi Aubry \& Acri (2004) reported a maximum value of $\mathrm{H}^{\prime}$ that barely touches 3 bits.cell.-1, whereas in the Berre pond (France) this index was around 2 bits.cell.-1 (Beker, 1986).

Our results revealed the existence of three potentially toxic species belonging to the group of diatoms: Pseudo-nitzschia delicatissima, P. seriata and Thalassionema nitzschoides. These species have been reported to produce domoid acid respon- sible of ASP (Amnesic Shellfish Poisoning) syndrome. The most abundant potentially harmful species is Pseudo-nitzschia delicatissima (up to 2520 cells. $L^{-1}$ ). Cell densities of $P$. seriata and $T$. nitzschoides were usually low and often imperceptible in quantitative samples, their maximum abundances ranging between 210 and 700 cells. $\mathrm{L}^{-1}$. The appearance of these three potentially toxic species occurs in late summer and autumn; this situation is an alarm for shellfish farmers in the lagoon which could be confronted to harmful blooms and intoxication of the mollusks in the near future. Sahraoui et al. (2009) reported the presence of toxic Pseudonitzschia species in Bizerte lagoon (Tunisia). In French coastal waters, Pseudo-nitzschia are known to bloom during the spring (Quiroga, 2006).

In conclusion, it appears: (1) Unlike the majority of Mediterranean lagoons, which are eutrophic, the Mellah lagoon is distinguished by its meso-oligotrophy, due to its remoteness from any source of pollution. (2) Despite the limitation of nutrients in this lagoon, it holds a diatom specific richness which exceeds that of many lagoons in the Mediterranean. (3) The optimal conditions for the development of diatoms in the lagoon correspond to the phases where the water temperature is moderate in parallel to the increase of the nutrients input (firstly with PO4 and secondary with NH4), that is during the seasonal transition periods spring-summer and summer-autumn. (4) The presence of some potentially toxic species, nowadays three in number, points out the need of the establishment of a regular monitoring of harmful species - as shellfish culture has been practiced for several years in this lagoon to reduce (or even avoid) the risk of human intoxication.

\section{ACKNOLEDGMENTS}

This work was carried out with the financial assistance of Souk Ahras University (Algeria). Authors thank all who have facilitated the realization of this scientific contribution.

\section{REFERENCES}

Ayadi H., Abid O., Elloumi J., Bouaïn A. \& SimeNgando T., 2004. Structure of the phytoplankton 
communities in two lagoons of different salinity in the Sfax saltern (Tunisia). Journal of Plankton Research, 26: 669-679. https://doi.org/10.1093/plankt/ fbh047

Badosa A., Boi D., Brucet S., López-flores R., \& Quintana X.D., 2008. Short-term variation in the ecological status of a Mediterranean coastal lagoon (NE Iberian Peninsula) after a man-made change of hydrological regime. Aquatic Conservation: Marine and Freshwater Ecosystems, 18: 1078-1090. https://doi. org/10.1002/aqc. 898

Béjaoui B., Ferjani D., Zaaboubi N., Chapelle A. \& Moussa M., 2010. Caractérisation hydrobiologique saisonnière de la lagune de Bizerte (Tunisie). Revue des sciences de l'eau, 23: 215-232.

Beker B., 1986. Communautés phytoplanctoniques en milieu côtier à salinité variable (Étang de Berre et Golfe de Fos). University Research Degree Thesis, Univ. Aix Marseille II, 114 pp.

Bellakhal Fartouna M. \& Bellakhal M., 2013. Fluctuations spatio-temporelles du peuplement phytoplanctonique au niveau d'un écosystème lagunaire au nord de la Tunisie. Rapport de la Commission internationale Mer Méditerranée, 40: 723.

Bernardi Aubry F. \& Acri F., 2004. Phytoplankton seasonality and exchange at the inlets of the Lagoon of Venice (July 2001-June 2002). Journal of Marine Systems, 51: 65-76. https://doi.org/10.1016/j. jmarsys.2004. 05.008

Bernardi Aubry F., Acri F., Bianchi F. \& Pugnetti A., 2013. Looking for patterns in the phytoplankton community of the Mediterranean microtidal Venice Lagoon: evidence from ten years of observations. Scientia Marina, 77: 47-60. https://doi.org/10.3989/ scimar.03638.21A

Benrejeb-Jenhani A. \& Romdhane M.S., 2002. Impact des perturbations anthropiques sur l'évolution du phytoplancton de la lagune de Boughrara (Tunisie). Bulletin de l'Institut National des Sciences et Technologie de la Mer de Salammbô, 29: 65-75.

Bianchi F., Acri F., Bernardi-Auby F., Berton A., Boldrin A., Camatti E., Cassin D. \& Comaschi A., 2003. Can plankton be considered a bio-indicator of water quality in the lagoon of Venice? Marine Pollution Bulletin, 46: 964-971. https://doi.org/10.1016/S0025326X(03)00111-5

Bonin D.J., 1988. Rôle du phosphate organique dissous dans la production primaire. Oceanis, 14: 381-387.

Cañedo-Argüelles M., Rieradevall M., Farrés-Corell R. \& Newton A., 2012. Annual characterisation of four Mediterranean coastal lagoons subjected to intense human activity. Estuarine, Coastal and Shelf Science, 114: 59-69. https://doi.org/10.1016/j.ecss.2011.07. 017

Caroppo C., Congestri R., Bracchini L. \& Albertano P., 2005. On the presence of Pseudo-nitzschia calliantha
Lundholm, Moestrup \& Hasle and Pseudo-nitzschia delicatissima (Cleve) Heiden in the Southern Adriatic Sea (Mediterranean Sea, Italy). Journal of Plankton Research, 27: 763-774. https://doi.org/10.1093/ plankt/fbi050

Chrétiennot-Dinet M.J, Sournia A., Ricard M. \& Billard C., 1993. A classification of the marine phytoplankton of the word from class to genus. Phycologia, 32: 159-179.

Dhib A., Denis M., Barani A., Turki S. \& Aleya L., 2016. Ultra- and microplankton assemblages as indicators of trophic status in a Mediterranean lagoon. Ecological Indicators, 64: 59-71. https://doi.org/10.1016/j. ecolind.2015.12.032

Dinno A., 2017. Dunn.test: Dunn's Test of Multiple Comparisons Using Rank Sums. R package version 1.3.5. https://CRAN.R-project.org/package=dunn.test

Drira Z., Bel Hassen M., Hamza A., Rebai A., Bouain A., Ayadi H. \& Aleya L., 2009. Spatial and temporal variations of microphytoplankton composition related to hydrographic conditions in the Gulf of Gabes. Journal of the Marine Biological Association of the United Kingdom, 89: 1559-1569.

Drira Z., Elloumi J., Guermazi W., Bel Hassen M., Hamza A \& Ayadi H., 2014. Seasonal changes on planktonic diatom communities along an inshore-offshore gradient in the Gulf of Gabes (Tunisia). Acta Ecologica Sinica, 34: 34-43.

Dufour P., Albaret J.J., Durand J.R. \& Guiral D., 1994. Les milieux aquatiques lagunaires. I: Environnement et ressources aquatiques de Côte d'Ivoire, tome II. Durand J.R., Dufour Ph., Guiral D. \& Zabi S. (Eds.), Les milieux lagunaires. Editions de l'ORSTOM: 509-527 pp.

El Madani F., Chiaar A. \& Chafi A., 2011. Phytoplankton composition and abundance assessment in the Nador lagoon (Mediterranean coast of Morocco). Acta Botanica Croatia, 70: 269-288.

FAO, 1987. Aménagement du chenal du lac Mellah. Rapport FAO et Ministère de l'hydraulique, de l'environnement et des forêts, division de développement des activités hydrauliques et agricoles, note préliminaire, janvier 1987, $25 \mathrm{pp}$.

Hasle G.R., Syvertsen E.E., Steidinger K.A. \& Tangen K., 1996. Marine Diatoms. In: Tomas C.R. (Ed.), Identifying Marine Diatoms and Dinoflagellates. Academic Press, New York, 429 pp.

Hendey N.I., 1964. An introductory account of the smaller algae of British coastal waters. Part V: Bacillariophyceae, Diatoms. Fishery Investment, London, Ser. IV, 5: $317 \mathrm{pp}$.

Ihaka R. \& Gentleman R., 1996. R: A language for data analysis and graphics. Journal of Computational and Graphical Statistics, 5: 299-314.

Kale A. \& Karthick B., 2015. The diatoms: Big Significance of Tiny Glass Houses. Resonance, 20: 919-930. 
Kassambara A. \& Mundt F., 2017. factoextra: Extract and Visualize the Results of Multivariate Data Analyses. R package version 1.0.5. https://cran.r-project.org/ package $=$ factoextra

Khairy H.M \& Gharib S.M., 2017. Factors Regulating Composition and Abundance of Phytoplankton in El Dekhaila Harbor, South-Eastern Mediterranean Sea, Egypt. Asian Journal of Biological Sciences, 10: $27-$ 37. https://doi.org/10.3923/ajbs.2017.27.37

Knoppers B., 1994. Aquatic Primary Production in Coastal Lagoons. In: Kjerfve B. (Ed.), Coastal lagoon processes. Amsterdam, Elsevier Oceanography, 60: 243-285.

Lefebvre K.A. \& Robertson A., 2010. Domoic acid and human exposure risks: a review. Toxicon, 56: 218 230. https://doi.org/10.1016/j.toxicon.2009.05.034

Lenzi M., Palmieri R. \& Porello S., 2003. Restoration of the trophic Orbetello lagoon (Tyrrhenian Sea, Italy), water quality management. Estuarine, Coastal and Shelf Science, 132: 99-107.

Licursia M. \& Gómeza N., 2013. Short-term toxicity of hexavalent-chromium to epipsammic diatoms of a microtidal estuary (Rio de la Plata): responses from the individual cell to the community structure. Aquatic Toxicology, 82: 134-135. https://doi.org/10. 1016/j.aquatox.2013.03.007

Mallissen M.O. \& Lasserre P., 1979. Évolution saisonnière des populations de diatomées benthiques dans les lagunes aménagées de Certes. CNEXO, Actes de colloque, 7: 543-558.

Mann D.G., 1999. The species concept in diatoms. Phycologia, 38: 437-495.

Marinov D., Zaldíva J.M., Norro A., Giordani G. \& Viaroli P., 2008. Integrated modelling in coastal lagoons: Sacca di Goro case study. Hydrobiologia, 611: 147-165.

Mozetic P., Fonda Umani S., Ctaletto B. \& Malej A., 1998. Seasonal and inter-annual planktonic variability in the Gulf of Trieste (northern Adriatic). ICES Journal of Marine Sciences, 55: 711-722.

Nassar M.Z.A. \& Gharib S.M., 2014. Spatial and temporal patterns of phytoplankton composition in Burullus Lagoon, Southern Mediterranean Coast, Egypt. Egyptian Journal of Aquatic Research, 40: 133-142. https://doi.org/10.1016/j.ejar.2014.06.004

OECD, 1982. Eutrophication of waters; monitoring, assessment and control. Organisation for Economic and Cooperative Development (OECD), Paris, France, $154 \mathrm{pp}$

Ounissi M., Haridi A. \& Rétima A., 2002. Variabilité du zooplancton de la lagune Mellah (Algérie) selon l'advection tidale en hiver et au printemps 1996-1997. Journal de Recherche Océanographique, 27: 1-13.

Pachés M., Romero I., Martínez-Guijarro R., Martí C.M. \& Ferrer J., 2014. Changes in phytoplankton compo- sition in a Mediterranean coastal lagoon in the Cullera Estany (Comunitat Valenciana, Spain). Water and Environment Journal, 28: 135-144. https://doi. org/10.1111/wej. 12020

Percopo I., Siano R., Cerino F., Sarno D. \& Zingone A., 2011. Phytoplankton diversity during the spring bloom in thenorthwestern Mediterranean Sea. Botanica Marina, 54: 243-267. https://doi. org/10.1515/ BOT.2011.033

Piélou E.C., 1966. The measurement of diversity in different types of biological collection. Journal of Theoretical Biology, 13: 131-144.

Quiroga I., 2006. Pseudo-nitzschia blooms in the Bay of Banyuls-sur-Mer, northwestern Mediterranean Sea. Diatom Research, 21: 91-104. https://doi.org/10. 1080/0269249X.2006.9705654

R Core Team, 2017. A Language and Environment for Statistical Computing. R Foundation for Statistical Computing, Vienna, Austria. http://cran.r-projet.org/.

Rekik A., Ayadi H. \& Elloumi J., 2017. Coupling of phytoplankton community structure to nutrients, ciliate and zooplankton around the Bessila Island (Kneiss Islands, central Mediterranean Sea). SDRP Journal of Earth Sciences \& Environmental Studies, 2: 201211. https://doi.org/10.25177/JESES.2.2.5

Ricard M., 1987. Atlas du phytoplancton marin. Vol. II: Diatomophyceaes. Editions CNRS. Paris, France, 297 pp.

Roselli L., Fabbrocini A., Manzo C. \& D’Adamo R., 2009. Hydrological heterogeneity, nutrient dynamics and water quality of a non-tidal lentic ecosystem (Lesina Lagoon, Italy). Estuarine, Coastal and Shelf Science, 84: 539-552. https://doi.org/10.1016/j.ecss. 2009.07.023

Round F.E., Crawford R.M. \& Mann D.G., 1990. The diatoms: biology and morphology of the Genera. Cambridge University Press, Cambridge, 747 pp.

Sahraoui I., Sakka Hlaili A., Hadj Mabrouk H., Leger C. \& Bates S.S., 2009. Blooms of the diatom genus Pseudo-nitzschia H. Peragallo in Bizerte lagoon (Tunisia, SW Mediterranean). Diatom Research, 24: 175-190.

Satta C.T., Anglès S., Garcés E., Sechi N., Pulina S., Padedda B.M., Stacca D. \& Lugliè L., 2014. Dinoflagellate Cyst Assemblages in Surface Sediments from Three Shallow Mediterranean Lagoons (Sardinia, North Western Mediterranean Sea). Estuaries and Coasts, 37: 646-663. https://doi.org/10.1007/s12237013-9705-1

Shannon C.E. \& Weaver W., 1949. The mathematical theory of communication. Urban: University of Illinois Press.

Solak C.N., Kulikovskiy M., Kiss T.K., Kaleli M.A, Kociolek J.P., Ács É., 2018. The distribution of centric diatoms in different river catchments in the Anatolian 
Peninsula, Turkey. Turkish Journal of Botany, 42: 100-122.

Souchu P., Becquert B., Smith V.H, Laugier T., Fiandrino A., Benau L., Orsoni V., Collos Y. \& Vaquer A., 2010. Patterns in nutrient limitation and chlorophyll a along an anthropogenic eutrophication gradient in French Mediterranean coastal lagoons. Canadian Journal of Fisheries and Aquatic Sciences, 67: 743753. https://doi.org/10.1139/F10-018

Sournia A., 1986. Atlas du phytoplancton marins Vol I. Introduction, Cyanophycées, Dictyophycées, Dinophycées et Raphidophycées. Editions CNRS, Paris, $219 \mathrm{pp}$.

Taş S., 2014. Phytoplankton composition and abundance in the coastal waters of the Datça and Bozburun Peninsulas, south-eastern Aegean Sea (Turkey). Mediterranean Marine Science, 15: 84-94. https:// doi.org/10.12681/mms.418

Tomas C.R., 1996. Identifying Marine Diatoms and Dinoflagellates. Academic Press, Inc. Harcourt Brace \& Company, San Diego, 598 pp.

Trainer V.L., Hickey B., Bates S.S., 2008. Toxic diatoms. In: Walsh P.J., Smith S.L., Fleming L.E., Solo-
Gabriele H. \& Gerwick W.H. (Eds.), Oceans and human health: risks and remedies from the sea. Elselvier Science Publishers, New York, 219-237.

Utermöhl H. 1958. Zur Vervollkommnung der quantitativen phytoplankton methodik. International Association of Theoretical and Applied Limnology, 9: 1-38. Viaroli P., Giordani G., Bartoli M., Naldi M., Azzoni R., Nizzoli D., Ferrari I., Zaldívar J.M., Bencivelli S., Castaldelli G. \& Fano E.A., 2006. The Sacca di Goro and an arm of the Po River. In: Wangersky P.J. (Ed.), The Handbook of Environmental Chemistry, Estuaries, Vol. 5/H. Springer-Verlag, Berlin: 197-232.

Yool A. \& Tyrrell T., 2003. Role of diatoms in regulating the ocean's silicon cycle. Global Biogeochemical Cycles, 17: 1103-1124. https://doi.org/10.1029/2002 GB002018

Zaaboub Nounis A., Helali M.A., Béjaoui B., Lillebø A.I., Ferreira da Silva E. \& Aleya L., 2014. Phosphorus speciation in sediments and assessment of nutrient exchange at the water-sediment interface in a Mediterranean lagoon: Implications for management and restoration. Ecological Engineering, 73: 115125. 